KONSTRUKTIVISME, Vol. 10, No. 2, Juli 2018

p-ISSN: 1979-9438; e-ISSN: 2442-2355

FKIP Universitas Islam Balitar, Blitar

Http://konstruktivisme.unisbablitar.ejournal.web.id; Email: konunisba@gmail.com

\title{
PENGARUH MEDIA AUDIO VISUAL TERHADAP PENGUASAAN KONSEP SISTEM PENCERNAAN MANUSIA KELAS VIII SMP 1 PATRA MANDIRI PLAJU
}

\author{
Fitri Oviyanti1), Syarifah2), Vivi Weliyani3) \\ 1), 2), 3)Prodi Pendidikan Biologi Fakultas IImu Tarbiyah dan Ilmu Keguruan \\ Universitas Islam Negeri Raden FatahPalembang, \\ JI. Prof. K.H. Zainal Abidin Fikri No. 1 A Km 3,5, Palembang 30126, Indonesia, \\ Email: 1)fitrioviyanti uin@radenfatah.ac.id ${ }^{2}$ syarifah uin@radenfatah.ac.id, \\ 3)vivikim17@gmail.com
}

\section{ABSTRAK:}

Pembelajaran yang menekankan siswa untuk membentuk pemahaman sendiri, merupakan cara yang efektif untuk meningkatkan penguasaan konsep. Salah satu media pembelajaran yang dapat meningkatkan penguasaan konsep adalah media audio visual berupa video. Penelitian ini bertujuan mengetahui pengaruh penggunaan audio visual terhadap penguasaan konsep siswa. Jenis penelitian eksperimen semu (Quasi Eksperimen). Desain penelitian ini adalah Nonequivalent Control Group Design. Populasi penelitian ini adalah siswa kelas VIII SMP 1 Patra Mandiri Plaju. Sampel penelitian ini kelas VIII sebagai kelas eksperimen dan $\mathrm{VIII}_{\mathrm{B}}$ sebagai kelas kontrol yang dipilih secara purposive sampling. Pada proses pembelajaran, kelas eksperimen diajarkan dengan menggunakan media Audio visual berupa video dan kelas kontrol diajarkan dengan media power point (PPT). Pengambilan data menggunakan tes penguasaan konsep dengan bentuk pilihan ganda terbuka yang telah diuji validitas dan reliabilitasnya. Data kuantitatif diperoleh dari rata-rata nilai pretes, postes, dan $\mathrm{N}$-gain yang dianalisis menggunakan uji t. Hasil penelitian uji hipotesis data Posttest menunjukan bahwa nilai Sig $=0,118>0,05$. Sedangkan nilai $t_{\text {hitung }}=1,766>t_{\text {tabel }}=$ 1,684. Nilai rata-rata $\mathrm{N}$-gain Pretest-Posttest kelas eksperimen 0,67 termasuk kategori sedang, sedangkan nilai rata-rata $\mathrm{N}$-gain PretestPosttest kelas kontrol adalah 0,57 termasuk kategori sedang. Berdasarkan hasil penelitian dapat disimpulkan bahwa penerapan media Audio Visual berupa video berpengeruh secara signifikan terhadap 
Fitri Oviyanti1), Syarifah'), Vivi Weliyani ${ }^{3}$. 2018. Pengaruh Media Audio Visual terhadap Penguasaan Konsep Sistem Pencernaan Manusia Kelas VIII SMP 1 Patra Mandiri Plaju. Konstruktivisme, 10 (2): 193-203

penguasaan konsep siswa pada materi sistem pencernaan manusia kelas VIII SMP 1 Patra Mandiri Plaju.

Kata kunci: audio visual, penguasaan konsep, sistem pencernaan manusia

\section{ABSTRACT:}

Learning that emphasizes students to shape their own understanding, is an effective way to improve the mastery of concepts. One of the learning media that can improve the mastery of the concept is the audio visual media in the form of video. This study aims to determine effect use of audio visual to mastery of student concepts. The type of quasiexperimental research (Quasi Eksperimen). The design of this research is Nonequivalent Control Group Design. The population of this study were students of grade VIII SMP 1 Patra Mandiri Plaju. The sample of this study class VIIIA as experimental class and VIIIB as a control class selected by purposive sampling. In the learning process, the experimental class is taught by using Audio visual media in the form of video and control class is taught with power point media (PPT). Data retrieval uses conception master test with open multiple choice form which has been tested for its validity and reliability. Quantitative data were obtained from the mean of pretest, postes, and $\mathrm{N}$-gain values analyzed by t test. Result of research of hypothesis test of Posttest data shows that value of $\mathrm{Sig}=0,037<0,05$. While the value of tcount $=2.152>$ ttable $=1.684$. The average value of $\mathrm{N}$ gain Pretest-Posttest experimental class is 0.67 classified, while the average value of $\mathrm{N}$-gain Pretest-Posttest control class is 0.55 including medium category. Based on the results of research can be concluded that the application of Audio Visual media in the form of video influential significantly to the mastery of student concepts on the material of human digestive system class VIII SMP 1 Patra Mandiri Plaju.

Keywords: audio visual, mastery of concepts, human digestion system

\section{PENDAHULUAN}

Pembelajaran sains di Indonesia, khususnya pada mata pembelajaran Biologi, dapat menghantarkan siswa menguasai konsep-konsep dan 
Fitri Oviyanti1), Syarifah'), Vivi Weliyani ${ }^{3}$. 2018. Pengaruh Media Audio Visual terhadap Penguasaan Konsep Sistem Pencernaan Manusia Kelas VIII SMP 1 Patra Mandiri Plaju. Konstruktivisme, 10 (2): 193-203

keterkaitannya untuk dapat memecahkan masalah terkait dalam kehidupan sehari-hari. Kata menguasai disini mengisyaratkan bahwa pembelajaran Biologi harus menjadikan siswa tidak sekedar tahu dan hafal tentang konsepkonsep, melainkan harus menjadi siswa yang mengerti dan memahami serta menguasai konsep-konsep tersebut dan menghubungkan keterkaitan suatu konsep dengan konsep lain. Dengan kata lain, proses pembelajaran Biologi harus diupayakan menitikberatkan pada penguasaan konsep. Hal ini disebabkan karena konsep merupakan dasar bagi proses mental yang lebih tinggi untuk merumuskan prinsip dan generalisasi (Latif, 2013).

Menurut Hamalik "dalam" Rahma dkk (2015) mengemukakan bahwa pemakaian media pembelajaran dalam proses belajar mengajar dapat membangkitkan keinginan dan minat yang baru, membangkitkan motivasi rangsangan kegiatan belajar, dan bahkan membawa pengaruh-pengaruh psikologi terhadap siswa. Penggunaan media pembelajaran pada tahap orientasi pembelajaran akan sangat membantu keefektifan proses pembelajaran dan penyampaian pesan dan isi pembelajaran pada saat itu. Selain membangkit motivasi dan minat siswa, media pembelajaran juga dapat membantu siswa meningkatkan pemahaman, dan penyajian data dengan menarik serta terpecaya, memudahkan penafsiran data dan memadatkan informasi

Berdasarkan hasil observasi yang telah dilakukan di sekolah SMP 1 Patra Mandiri Plaju, diketahui bahwa sekolah ini sudah memiliki fasilitas belajar berupa LCD (Liquid Cristal Display) yang disambungkan dengan laptop/komputer, lalu diproyeksikan ke layar. Namun, penggunaan fasilitas ini masih jarang digunakan dalam proses belajar yang digunakan guru hanya berupa media gambar yang berasal dari buku ataupun cartha. Hal ini dibuktikan dari hasil wawancara peneliti dengan salah satu guru IPA yaitu ibu Evi S,Pd di SMP 1 Patra Mandiri Plaju. Salah satu kesulitan yang dihadapi adalah dalam hal penggunaan media audio visual yang belum begitu dipahami adalah dalam hal keterbatasan waktu yang dimilki guru saat proses belajar mengajar. Guru cenderung memakai seluruh waktu untuk memberikan penjelasan materi IPA dengan metode ceramah dan tidak menggunakan media sehingga akibatnya siswa cenderung pasif dalam proses pembelajaran. Pada tahun pembelajaran sebelumnya (2015/2016) sekitar $60 \%$ tidak mencapai kriteria tersebut. Dimana KKM yang telah diterapkan sekolah yaitu 75 .

Hal tersebut dikarenakan kurangnya penguasaan dan pemahaman terhadap materi yang disampaikan. Guru harus kreatif dalam meningkatkan hasil belajar siswa dengan cara memilih media pembelajaran yang tepat dan merangsang siswa untuk lebih aktif dalam pembelajaran khususnya pembelajaran Biologi. Berdasarkan wawancara dengan beberapa siswa kelas 
Fitri Oviyanti1), Syarifah²), Vivi Weliyani ${ }^{3}$. 2018. Pengaruh Media Audio Visual terhadap Penguasaan Konsep Sistem Pencernaan Manusia Kelas VIII SMP 1 Patra Mandiri Plaju. Konstruktivisme, 10 (2): 193-203

IX yang menyatakan bahwa materi sistem pencernaan manusia sulit untuk dimengerti dan dibutuhkan media yang dapat memberikan bukan hanya gambaran namun juga materi yang dapat dilihat secara langsung. Oleh karena itu, penelitian ini akan menerapkan media pembelajaran atau suatu upaya baru dalam proses belajar untuk tercapainya tujuan pembelajaran. Hal ini didukung juga oleh hasil penelitian Rinawati (2014), yang menyatakan bahwa penggunaan media audio visual dapat meningkatkan aktivitas belajar dan penguasaan konsep siswa. Berdasarkan uraian di atas, perlu dilakukan penelitian mengenai "Pengaruh Media Audio Visual Terhadap Pengusaan Konsep Sistem Pencernaan Manusia Kelas VIII SMP 1 Patra Mandiri Plaju”.

\section{METODE}

Waktu dan Tempat Penelitian

Penelitian ini telah dilaksanakan pada pada bulan Agustus sampai dengan September tahun 2017. Populasi pada penelitian ini adalah siswa kelas VIII SMP 1 Patra Mandiri Plaju.

Populasi dan Sampel Penelitian

Dalam penelitian ini yang menjadi populasi adalah seluruh kelas VIII SMP 1 Patra Mandiri yang terdiri dari 2 kelas dengan jumlah siswa seluruh adalah 46 siswa.

Tabel 1. Populasi kelas VII SMP 1 Patra Mandiri Plaju

\begin{tabular}{cccc} 
Kelas & $\mathbf{L}$ & $\mathbf{P}$ & Jumlah \\
\hline VIII A & 9 & 12 & 21 \\
VIII B & 12 & 11 & 23 \\
Jumlah & 21 & 23 & 44 \\
\hline
\end{tabular}

Sampel penelitian ini terdiri dari kelas $\mathrm{VIII}_{\mathrm{A}}$ eksperimen dan kelas $\mathrm{VIII}_{\mathrm{B}}$ sebagai kelas kontrol, yang diambil dengan teknik Purposive Sampling.

Tabel 2. Sampel Penelitian

\begin{tabular}{|c|c|c|c|c|}
\hline Kelas & L & $\mathbf{P}$ & $\begin{array}{c}\text { Jumlah } \\
\text { Siswa }\end{array}$ & Media \\
\hline VIII A & 10 & 13 & 23 & $\begin{array}{c}\text { media Audio } \\
\text { Visual }\end{array}$ \\
\hline $\begin{array}{l}\text { VIII B } \\
\text { Jumlah }\end{array}$ & $\begin{array}{l}12 \\
22\end{array}$ & $\begin{array}{l}11 \\
24\end{array}$ & $\begin{array}{l}24 \\
46\end{array}$ & media PPT \\
\hline
\end{tabular}


Fitri Oviyanti1), Syarifah²), Vivi Weliyani ${ }^{3}$. 2018. Pengaruh Media Audio Visual terhadap Penguasaan Konsep Sistem Pencernaan Manusia Kelas VIII SMP 1 Patra Mandiri Plaju. Konstruktivisme, 10 (2): 193-203

Design Penelitian

Penelitian ini menggunakan Non equevalent Control Group Design. Desain penelitian ini dapat digambarkan pada tabel sebagai berikut:

Tabel 3. Desain Nonequevalent Control Group

\begin{tabular}{lccc}
\hline Kelas & Pre-test & Treatment & Post-test \\
\hline Eksperimen & $\mathrm{O}_{1}$ & $\mathrm{X}_{1}$ & $\mathrm{O}_{2}$ \\
Kontrol & $\mathrm{O}_{3}$ & $\mathrm{C}$ & $\mathrm{O}_{4}$ \\
\hline
\end{tabular}

Keterangan:

$\mathrm{X} 1$

: Perlakuan menggunakan media audio visual (video)

C : Perlakuan menggunakan media PPT

$\mathrm{O}_{1}$ dan $\mathrm{O}_{2} \quad$ : Nilai test awal (pre-test)

$\mathrm{O}_{3}$ dan $\mathrm{O}_{4} \quad$ : Nilai test akhir (post-test)

\section{HASIL DAN PEMBAHASAN}

Hasil penelitian ini berupa data hasil belajar siswa dengan pembelajaran menggunakan media audio visual pada kelas eksperimen dan media power point (PPT) pada kelas kontrol. Data hasil belajar siswa diperoleh dari pretes dan postes untuk kelas eksperimen dan kontrol.

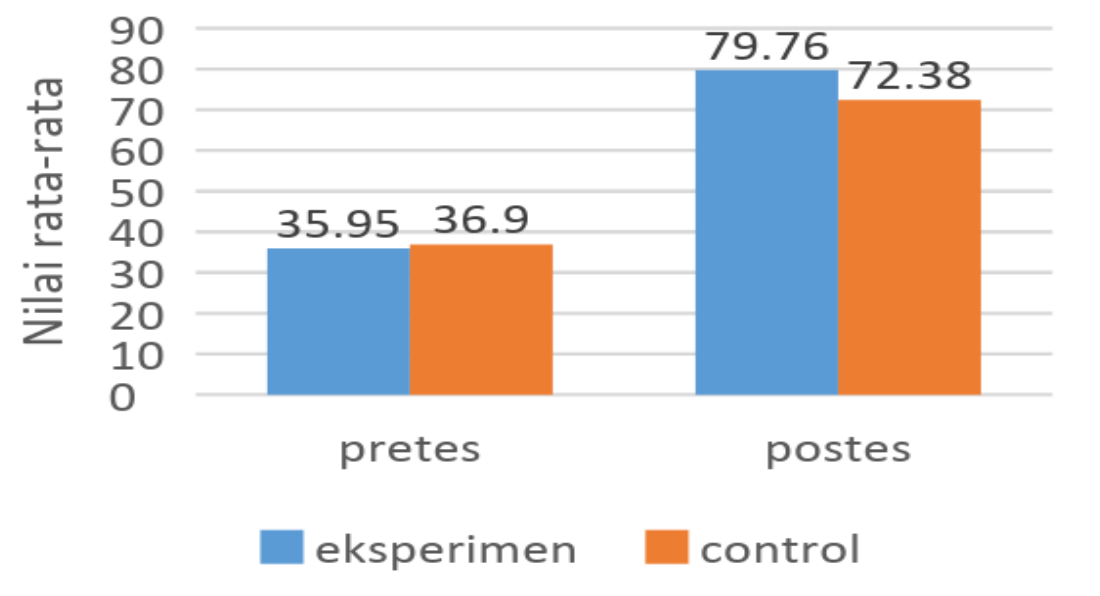

Gambar 1. Grafik rata-rata nilai pretest dan postest pada kelas eksperimen dan kelas kontrol 
Fitri Oviyanti1), Syarifah²), Vivi Weliyani ${ }^{3}$. 2018. Pengaruh Media Audio Visual terhadap Penguasaan Konsep Sistem Pencernaan Manusia Kelas VIII SMP 1 Patra Mandiri Plaju. Konstruktivisme, 10 (2): 193-203

Berdasarkan Gambar 1 di atas nilai pretest dan postes, kelas ekperimen lebih tinggi dibandingkan kelas kontrol. Untuk uji persyaratan analisis yang dipakai adalah uji statistik yang meliputi uji normalitas dan homogenitas. Teknik uji normalitas yang digunakan adalah teknik Kolmogorov-Smirnov sedangkan untuk uji homogenitas dengan teknik uji Levene Statistic. Kedua uji persyaratan analisis data dilakukan dengan bantuan program SPSS 22. Berikut adalah hasil dari uji normalitas data yang didapat dari Output SPSS.

Tabel 4. Hasil Uji Normalitas Posttest dengan Teknik Kolmogorov-Smirnow

\begin{tabular}{cccc} 
No. & Kelas & Signifikan & Keterangan \\
\hline 1 & Eksperimen & $0,073>0,05$ & Data berdistribusi normal \\
2 & Kontrol & $0,074>0,05$ & Data berdistribusi normal
\end{tabular}

Berdasarkan hasil uji normalitas yang telah didapatkan, dapat diketahui bahwa nilai uji normalitas untuk kelas ekperimen dan kelas kontrol yaitu sebesar 0,073 dan 0,074 >0,05, maka sesuai dengan dasar pengambilan keputusan dalam uji normalitas Kolmogorov-Smirnov, kedua data dinyatakan berdistribusi normal. Selanjutnya dilakukan uji homogenitas untuk menentukan kehomogenan sampel.

Tabel 5. Hasil Uji Homogenitas Posttest dengan Teknik Levene Statistic Test of Homogeneity of Variances Penguasaan_Konsep_Siswa

\begin{tabular}{cccc}
\hline Levene Statistic & df1 & df2 & Sig. \\
\hline 2,558 & 1 & 40 & 0,118
\end{tabular}

Berdasarkan hasil uji homogenitas yang telah didapatkan diketahui bahwa nilai signifikansi uji homogenitas untuk kelas eksperimen dan kelas kontrol yaitu sebesar $0,118>0,05$, maka dengan dasar pengambilan keputusan dalam uji homogenitas Levene Statistic, dapat dinyatakan bahwa kedua kelompok memiliki varian yang sama atau homogen. Uji hipotesis dilakukan dengan menggunakan Uji-t dengan bantuan program SPSS 22 . Berikut adalah hasil uji hipotesis (uji-t) data posttest didapat dari Output SPSS: 
Fitri Oviyanti1), Syarifah²), Vivi Weliyani ${ }^{3}$. 2018. Pengaruh Media Audio Visual terhadap Penguasaan Konsep Sistem Pencernaan Manusia Kelas VIII SMP 1 Patra Mandiri Plaju. Konstruktivisme, 10 (2): 193-203

Tabel 6. Hasil Uji Hipotesis Posttest dengan Uji-t

\begin{tabular}{cccccl}
\hline Kelas & Mean & $\mathbf{t}_{\text {hitung }}$ & $\mathbf{t}_{\text {tabel }}$ & Sig. & Kesimpulan \\
\hline Eksperimen & 15,95 & 1,766 & 1,684 & 0,118 & $\mathrm{H}_{\mathrm{a}}$ diterima \\
Kontrol & 14,76 & & & & $\mathrm{H}$ ditolak \\
\hline
\end{tabular}

Dari tabel di atas untuk nilai posttest pada kelas eksperimen dan kontrol diperoleh bahwa nilai $t_{\text {hitung }}$ sebesar 1,766 berdasarkan tabel distribusi, nilai $t_{\text {tabel }}$ untuk $d f=40$ adalah sebesar 1,684 dan nilai signifikansi 0,188<0,05. Dengan nilai $t_{\text {hitung }}>t_{\text {tabel }}$, maka sesuai dengan dasar pengambilan keputusan dalam uji-t Independent sample, dapat disimpulkan bahwa $\mathrm{H}_{0}$ ditolak dan $\mathrm{H}_{a}$ diterima artinya terdapat pengaruh media audio visual terhadap penguasaan konsep siswa di SMP 1 Patra Mandiri Plaju. Keputusan yang diperoleh adalah terima $\mathrm{H}_{\mathrm{a}}$, yang artinya siswa pada kelas ekperimen dan kelas kontrol pada materi sistem pencernaan manusia berbeda signifikan atau mempunyai penguasaan konsep yang berbeda. Perbedaan penguasaan konsep siswa sebagai akibat penerapan media audio visual sesuai dengan pendapat Fathurroman (2014), media merupakan alat yang digunakan untuk menyalurkan pesan atau informasi dari pengirim kepada penerima pesan. Dengan adanya media pembelajaran memberikan pengaruh yang baik bagi penguasaan siswa terbukti dengan naiknya hasil postest siswa yang artinya terjadi suatu proses yang dinamakan proses belajar.

Menurut Hamalik (2004), pemakaian media pembelajaran dalam proses belajar mengajar dapat membangkitkan keinginan dan minat yang baru, membangkitkan motivasi rangsangan kegiatan belajar, dan bahkan membawa pengaruh-pengaruh psikologi terhadap siswa. Penggunaan media pembelajaran pada tahap orientasi pembelajaran akan sangat membantu keefektifan proses pembelajaran dan penyampaian pesan dan isi pembelajaran pada saat itu. Selain membangkit motivasi dan minat siswa, media pembelajaran juga dapat membantu siswa meningkatkan pemahaman, dan penyajian data dengan menarik serta terpecaya, memudahkan penafsiran data dan memadatkan informasi Untuk uji statistik untuk $\mathrm{N}$-gain sebagai berikut : 
Fitri Oviyanti1), Syarifah'), Vivi Weliyani ${ }^{3}$. 2018. Pengaruh Media Audio Visual terhadap Penguasaan Konsep Sistem Pencernaan Manusia Kelas VIII SMP 1 Patra Mandiri Plaju. Konstruktivisme, 10 (2): 193-203

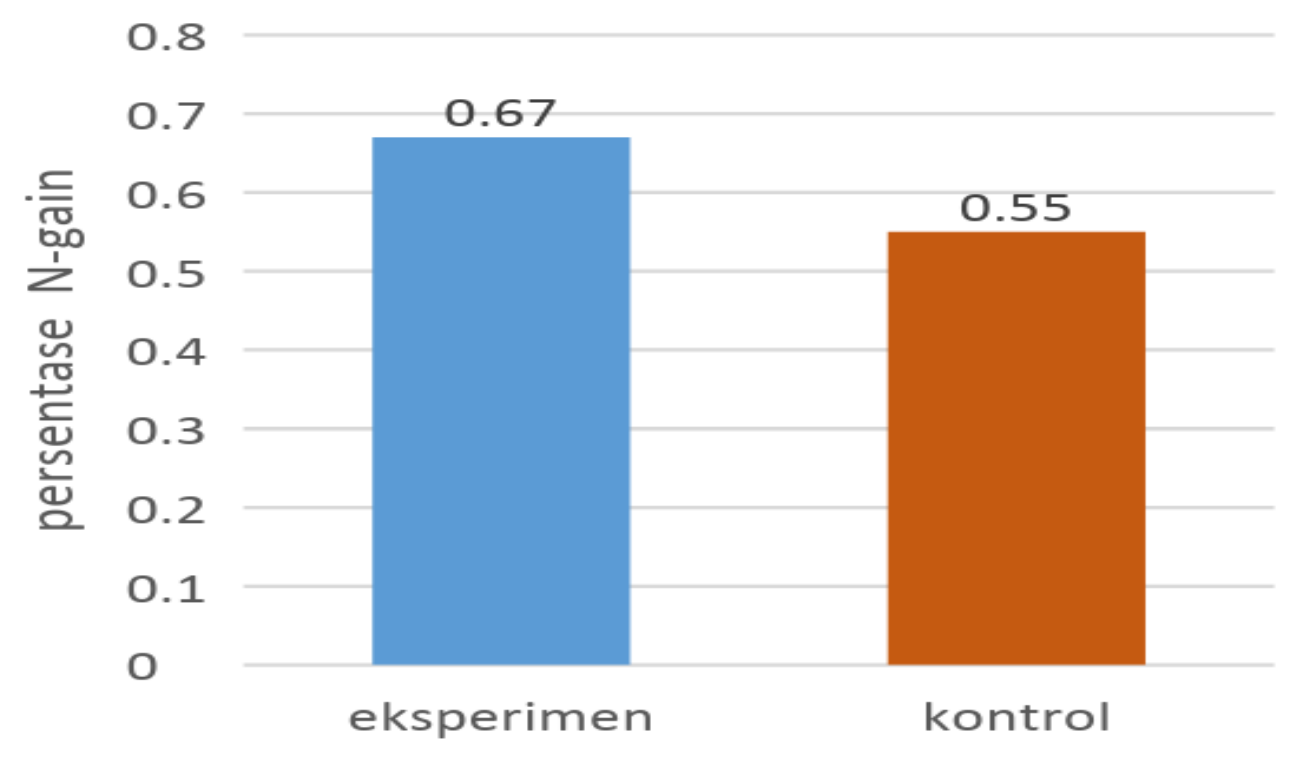

Gambar 2. Grafik nilai N-gain kelas eksperimen dan kelas kontrol

Hasil uji statistik untuk $\mathrm{N}$-gain menunjukan bahwa nilai rata-rata $\mathrm{N}$-gain pada kelas eksperimen signifikan terhadap kelas kontrol. Terjadi peningkatan nilai $\mathrm{N}$-Gain menunjukan terjadinya peningkatan penguasaan pada materi sistem pencernaan manusia, hasil yang didapat adalah antara kelas eksperimen dan kelas kontrol memiliki perbedaan N-Gain. Dimana kelas eksperimen menggunakan media Audio Visual dan kelas kontrol mengguanakan media Power Point (PPT). Tingginya penguasaan konsep siswa yang dibelajarkan menggunakan media Audio Visual lebih menarik sehingga merangsang ketertarikan siswa dalam mempelajari materi sistem pencernaan manusia, dimana siswa diberikan gambaran yang lebih nyata dengan adanya suara serta gerak yang membuat siswa ikut terlibat aktif dalam pembelajaran, sehingga timbul akan banyak pertanyaan dari siswa yang penasaran akan gambaran video yang ditampilkan guru.

Didukung oleh penelitian Imron (2014), peningkatan penguasaan konsep dipengaruhi oleh aktivitas belajar siswa selama pembelajaran dengan menggunakan media audio visual $74 \%$. Aktifitas pada aspek mengajukan pertanyaan dan juga mengerjakan LKS dengan media audio visual. Berikut persentasi ketuntasan $\mathrm{N}$-gain penguasaan konsep siswa : 
Fitri Oviyanti1), Syarifah'), Vivi Weliyani ${ }^{3}$. 2018. Pengaruh Media Audio Visual terhadap Penguasaan Konsep Sistem Pencernaan Manusia Kelas VIII SMP 1 Patra Mandiri Plaju.

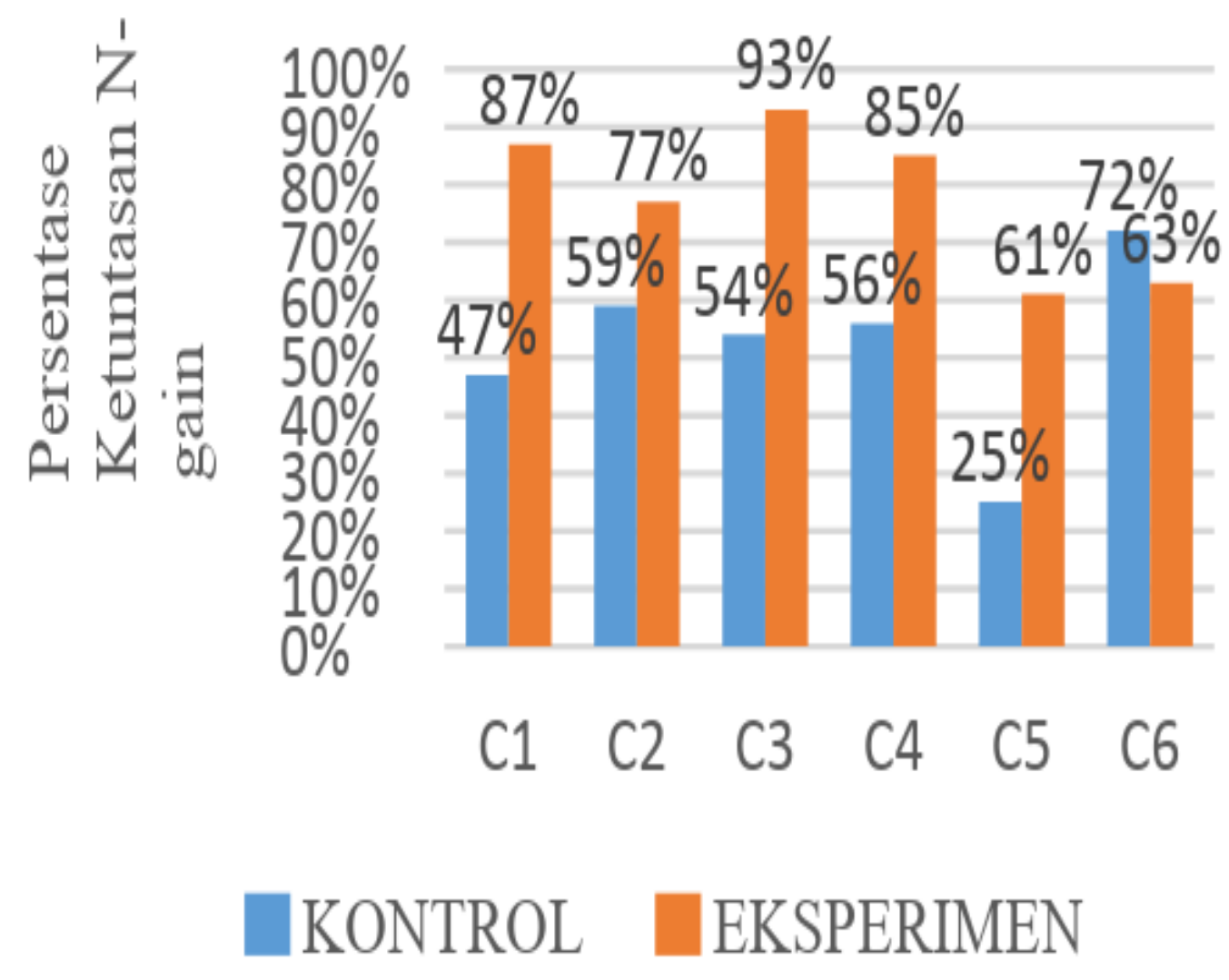

Gambar 3. Grafik N-gain pretest dan postest kelas eksperimen dan kelas kontrol

Gambar 3 menunjukan bahwa pada stiap indikator kognitif mengalami peningkatan, khususnya pada indikator $\mathrm{C} 1$ dan $\mathrm{C} 3$, kelas eksperimen memiliki nilai yang lebih tinggi dan berbeda signifikan dari kelas kontrol. Perbedaan penguasan konsep siswa antara kelas eksperimen yang diberikan pembelajaran dengan media Audio Visual dengan kelas kontrol dengan media Power Point (PPT). Media pembelajaran ini merupakan media yang menggunakan LCD (Liquid Cristal Display) yang disambungkan dengan laptop/komputer, lalu diproyeksikan ke layar. Kelas eksperimen menggunakan media Audio Visual siswa aktif dan antusias mengikuti pembelajaran ini dikarenakan media audio visual tidak hanya memberikan gambaran namun gambaran yang bergerak sehingga dapat merangsang minat belajar siswa serta siswa mengikuti pembelajaran yang menyenangkan dan siswa termotivasi untuk mengerjakan soal-soal yang diberikan. 
Fitri Oviyanti1), Syarifah²), Vivi Weliyani ${ }^{3}$. 2018. Pengaruh Media Audio Visual terhadap Penguasaan Konsep Sistem Pencernaan Manusia Kelas VIII SMP 1 Patra Mandiri Plaju. Konstruktivisme, 10 (2): 193-203

Menurut Rusman (2012), menyatakan bahwa penggunaan media pembelajaran dapat memberikan rangsangan bagi siswa untuk proses belajar. Hal ini didukung oleh hasil penelitian yang dilakukan oleh Andriyani (2014), peningkatan hasil belajar siswa terjadi karena pembelajaran menggunakan media Audio Visual teryata dapat menciptakan suasana belajar yang menyenangkan bagi siswa dan mampu membuat siswa aktif yang didukung data angket yang menyatakan bahwa hampir seluruh siswa $(94,43 \%)$ senang belajar menggunakan media Audio Visual.

Berdasarkan uraian diatas menunjukan bahwa perlakuan yang berbeda menyebabkan terjadinya hasil akhir yang berbeda antara kelompok eksperimen yang menggunakan media Audio Visual berupa video dengan kelompok kontrol yang menggunakan media Power Point (PPT). Dengan demikian, ternyata terbukti bahwa media Audio Visual berpengaruh terhadap penguasaan konsep sistem pencernaan manusia di Kelas VIII SMP 1 Patra Mandiri Plaju.

\section{SIMPULAN}

Berdasarkan hasil penelitian dapat disimpulkan bahwa penerapan media Audio Visual berupa video berpengaruh secara signifikan terhadap penguasaan konsep siswa. Hasil uji hipotesis data Posttest menunjukan bahwa nilai Sig $=0,118>0,05$. Sedangkan nilai $t_{\text {hitung }}=1,766>t_{\text {tabel }}=1,684$. Nilai rata-rata $\mathrm{N}$-gain Pretest-Posttest kelas eksperimen 0,67 termasuk kategori sedang, sedangkan nilai rata-rata N-gain Pretest-Posttest kelas kontrol adalah 0,57 termasuk kategori sedang.

\section{DAFTAR RUJUKAN}

Andriyani. (2014). Pengaruh Penggunaan Media Audio-Visual terhadap Aktivitas dan Hasil Belajar Siswa. [Skripsi]. Universitas Muhammadiyah Surakarta.

Fathurrohman dan Sobry Sutikno. (2014). Strategi Belajar Mengajar : Strategi mewujudkan pembelajaran bermakna melalui pemahaman konsep umum \& islami. Bandung: PT Refika Aditama.

Hamalik, O. (2004). Proses Belajar Mengajar. Bumi Aksara. Bandung.

Hamdayama, J. (2016). Metodologi Pengajaran. Bumi Aksara: Jakarta.

Imron rosadi. Pengaruh Audio Visual Terhadap Penguasaan Konsep Pada Materi Peristiwa Alam dan Dampaknya. [Skripsi]. Universitas Lampung. 
Fitri Oviyanti1), Syarifah'), Vivi Weliyani ${ }^{3}$. 2018. Pengaruh Media Audio Visual terhadap Penguasaan Konsep Sistem Pencernaan Manusia Kelas VIII SMP 1 Patra Mandiri Plaju. Konstruktivisme, 10 (2): 193-203

Latif, A. (2013). Model Pembelajaran untuk Meningkatkan Penguasaan Konsep Fisika SMA. Bandung: Universitas Pendidikan Indonesia.

Rinawati, D. (2014). Pengaruh Penggunaan Media Audio Visual pada Materi Pokok Keanekaragaman Ciri Makhluk Hiduo Terhadap Penguasaan Konsep dan Aktivitas siswa. [skripsi]. Universitas Lampung.

Rusman. (2012). Belajar Dan Pembelajaran Berbasis Komputer. Alfabeta. Bandung. 